\title{
水蒸気添加による $\mathrm{NO}_{\mathrm{x}}$ 低減に関する化学反応論的検討 ${ }^{\dagger}$
}

\author{
趙 黛青 $^{1 \dagger+} \cdot$ 山下博史 ${ }^{2} \cdot$ 山本 剛 $^{3} \cdot$ 古畑朋彦 $^{4} \cdot$ 新井紀男 $^{4}$
}

\author{
1新エネルギー・産業技術総合開発機構， 170-6028＼cjkstart東京都豊島区東池袋 3-1-1 \\ 2名古屋大学工学研究科機械情報システム工学専攻, 464-8603 名古屋市千種区不老町 \\ 3名古屋大学工学研究科分子化学工学専攻, 464-8603 名古屋市千種区不老町 \\ 4名古屋大学高温エネルギ一変換研究センター，464-8603 名古屋市千種区不老町
}

$\mathrm{NO}_{\mathrm{x}}$ の生成が Prompt 機構に支配される燃焼場において, 水蒸気添加による $\mathrm{NO}_{\mathrm{x}}$ の低減機構に関して は, 火资温度の低下という物理的な効果のほかに, 水蒸気に起因する種々の中間活性種 $(\mathrm{OH}, \mathrm{H}, \mathrm{CH}$ ど）の濃度の変化が引き起こす化学反応論的な効果があることが予想される. 本研究では, 対向流拡散火 炎について詳細素反応機構を用いた数値計算を行い, 初期温度を変化させて最高火炎温度が同一になるよ うに設定することにより，NO 低減に対する水蒸気添加の化学反応論的効果を比較検討した。光の結果, 最高火咨温度が同一という条件下でも, 水蒸気添加によりNOの Emission Index は低下し, NO 生成に 関連する CH, HCN, N などの漕度および生成速度も低下することが明らかとなり, $\mathrm{NO}_{\mathrm{x}}$ 低減に与える水 蒸気添加の化学反応論的な効果が解明された。

\section{緒言}

水蒸気を燃焼器中に噴射することにより $\mathrm{NO}_{\mathrm{x}}$ の生成を抑制す る技術が実用化されており，特に最近では，コージェネレーショ ンにおけるガスタービンの発電効率の改善策として，廃熱回収ボ イラーで発生した蒸気をガスタービンに噴射することで，高効率 かつ低公害を目指したチェンサイクル（Watanabe et al., 1997） や, ケミカルガスタービン発電システム (Arai et al., 1994, 1997) 等が提案されている．水蒸気噴射による火炎温度の低下は Thermal NOの抑制に有効であり，実際燃焼プロセスにも応用されて いる.この火炎温度の低下の原因としては，低温かつ高熱容量の 水蒸気添加という物理的な効果が考えられるが，火炎温度が同じ でも火炎中の水蒸気濃度が異なれば，水蒸気に起因する種々の中 間活性種 $\left(\mathrm{OH}, \mathrm{H}, \mathrm{CH}\right.$ など) の濃度が変化し， $\mathrm{NO}_{\mathrm{x}}$ 生成の素反 応過程に対して化学反応論的な効果を与えることも予想される。 特に, 燃料過濃燃焼や拡散燃焼の場合, $\mathrm{NO}_{\mathrm{x}}$ の生成が Prompt NO 機構に支配される（Takeno and Nishioka, 1998）ために，この ような効果が無視できないものと考えられる.

これに関して，宮内ら（Miyauchi and Mori, 1980）は層流予 混合火炎の数值解析と, 対応する実験により, 当量比 1.2 の燃料過 濃予混合気に水蒸気を火炎温度を一定に保ちながら添加した場合, $10 \mathrm{~mol} \%$ 以上添加すると急激に $\mathrm{NO}_{\mathrm{x}}$ が減少することを示した.

最近, Li ら（Li et al., 1997）は燃料過濃予混合気と水噴霧を付 加された空気による対向流二重火炎の数值解析を行い, 水蒸気が メタンの分解生成物 $\mathrm{CHi}$ と反応し, $\mathrm{NO}_{\mathrm{x}}$ 生成に関与する $\mathrm{CH}$ ラ ジカルの濃度が減少するという反応動力学的な効果があることを 指摘している. しかしながら，水蒸気を添加した場合の $\mathrm{NO}_{\mathrm{x}}$ の生 成機構に関する化学反応論的な効果はまだ十分には解明されてい ない．また，ガスタービンの場合は，タービンブレードの耐久性 などを考える上で, 水蒸気添加による $\mathrm{OH}$ ラジカル濃度の上昇が

\footnotetext{
† 1999 年 2 月 22 日受理

化学工学会第 31 回秋季大会 (米沢, 1998 年 9 月) にて発表

†† zhao@nuce.nagoya-u.ac.jp
}

予測され，これによる材料劣化の影響については検討はほとんど なされていない.

著者らは燃焼器に多く応用されている拡散火炎の基本的な形態 の一つである対向流について, 現在最も信頼されている $\mathrm{NO}_{\mathrm{x}}$ 生成 反応を含む詳細素反応機構 GRI-Mech (GRI, 1995) を用いて数值 解析を行った (Yamashita et al., 1998). その結果, 水蒸気を添 加することによる火炎温度の低下と Prompt NO 生成において重 要な $\mathrm{CH}, \mathrm{HCN}$ および $\mathrm{N}$ ラジカルの濃度の減少が $\mathrm{NO}_{\mathrm{x}}$ 低減の主 な要因であることを明らかにした，なお，対向流火炎はより一般 的な流れ場である噴流の場合と同様な特徵を有していることが確 かめられている (Yamashita, 1999).これらの研究を踏まえ, 本 研究では, 水蒸気添加量を変化させた場合について, 火炎温度低 下の影響を除いて化学反応論的効果のみを抽出して考察するため に, 対向流の初期温度を変化させて最高火炎温度が同一になるよ うに設定することにより， $\mathrm{NO}_{\mathrm{x}}$ 低減に対する水蒸気添加の影響を 比較検討した。

なお, 水蒸気が燃焼状態や火炎構造に与える効果の内, 水蒸気 の初期温度や熱容量のような「物理的な効果」を除いたものを, 一般的に「化学反応論的な効果」と呼び, また, そのような化学 反応論的な効果の中で, 詳細な素反応機構を基づき, $\mathrm{NO}_{\mathrm{x}}$ 生成の 素反応過程や種々の中間活性種の濃度や生成速度に言及しなけれ ばできないような効果を, 特に「反応動力学的な効果」と呼ぶこ とにする.

\section{1. 解析モデルと計算条件}

本研究では二次元の平面対向流層流拡散火炎を対象とした。解 析モデルの概略を Fig. 1 に示す.二つの噴射面間の距離を $L$ と し, 噴射面は $y$ と $z$ 方向で無限に広く,$x=0$ の噴射面からは燃料 メタン, $x=L$ の噴射面からは空気が噴出する. 面間の距離 $L$ は $15 \mathrm{~mm}$ とし, 燃料側噴射速度 $u_{\text {fuel }}$ と空気側噴射速度 $u_{\text {alr }}$ はいず れも $1 \mathrm{~m} / \mathrm{s}$ とする.このときの速度勾配 $\left(u_{\text {fuel }}+u_{\text {arr }}\right) / L$ は 133.3 $\mathrm{s}^{-1}$ となる.このような場合には，よどみ面は二つの噴射面間の燃 料側寄りに，また火炎面はこのよどみ面の空気側に形成される. 水蒸気は質量分率 $Y_{\mathrm{H}_{2} 0,0}=0.05$ あるいは 0.1 で, 空気側に添加す 


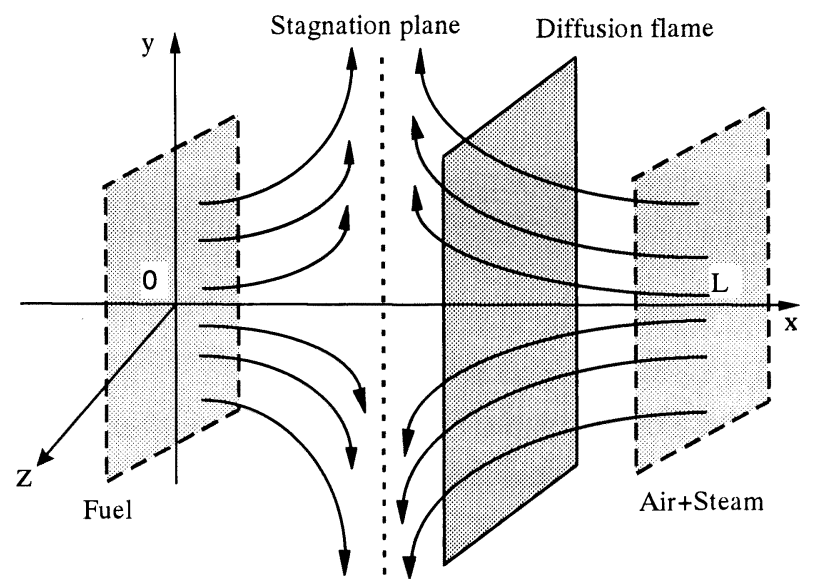

Fig. 1 Theoretical model of counterflow diffusion flame

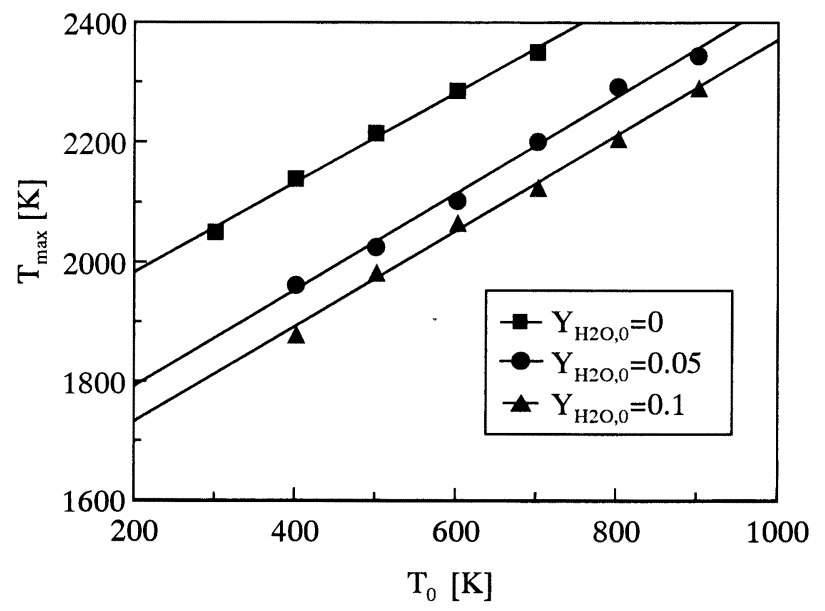

Fig. 2 Effect of initial temperature on maximum flame temperature

る.両噴射面の初期温度 $T_{0}$ は等しく, 300 $900 \mathrm{~K}$ の範囲で設定し た.

流れ場は平面二次元ポテンシャル流とし, 温度場と濃度場には 相似解が適用できるものとし，燃焼場を一次元的に解いた．数值 計算には山下 (Yamashita, 1999) の燃焼計算コードを用いた．計 算領域の差分格子数は 201 , 計算の時間刻みは $1 \mu \mathrm{s}$ とした. 化学 反応機構としては, $\mathrm{NO}_{\mathrm{x}}$ の生成反応を含む詳細素反応機構 GRIMech (GRI, 1995) を用いた. この反応機構では 49 個の化学種に ついて, 正逆 279 組の素反応を考えている. 以下では, この反応機 構の素反応番号を「R 180」のように引用する．計算に必要な熱力 学データは CHEMKIN データベース（Kee et al., 1993）から求 め, 輸送係数は Simplified Transport Model (Smooke, 1991) により算出した。

$\mathrm{NO}_{\mathrm{x}}$ の生成を定量的に検討するため, 火炎中の化学種 $k$ の単位 火炎面面積当たりの質量生成速度 $M_{\mathrm{k}}$ および Emission Index $E I_{\mathrm{k}}$ (Takeno and Nishioka, 1993）を用いた。ここで， $M_{\mathrm{k}}$ は局所質 量生成速度 $w_{\mathrm{k}}$ を次式のように火炎面に垂直方向に積分すること によって求める.

$$
M_{\mathrm{k}}=\int_{0}^{L} w_{\mathrm{k}} d x \quad\left[\mathrm{~kg} /\left(\mathrm{m}^{2} \cdot \mathrm{s}\right)\right]
$$

また，化学種 $k$ の Emission Index $E I_{\mathrm{k}}$ は次式によって定義さ れる。

$$
E I_{\mathrm{k}}=M_{\mathrm{k}} /\left(-M_{\mathrm{CH}_{4}}\right) \quad[\mathrm{g} / \mathrm{kg}]
$$

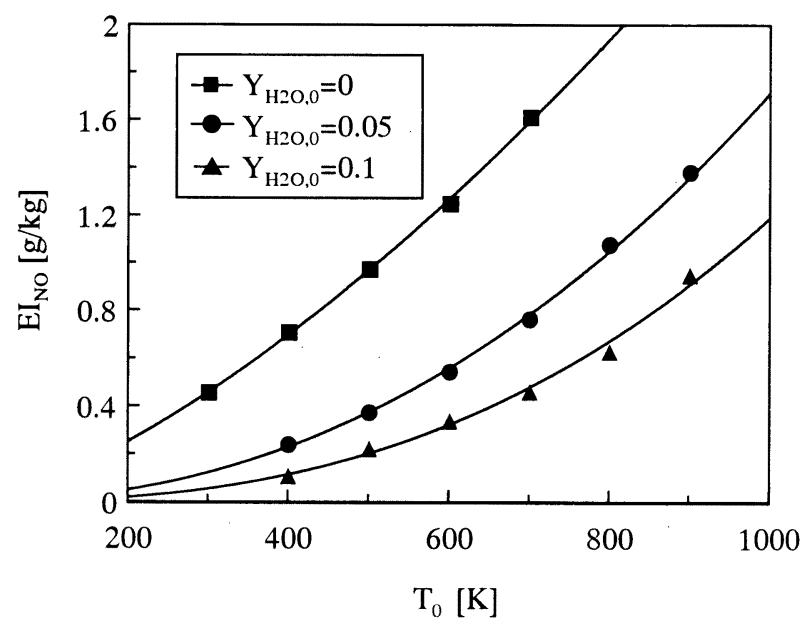

Fig. 3 Effect of initial temperature on NO emission index $E I_{\mathrm{N} O}$

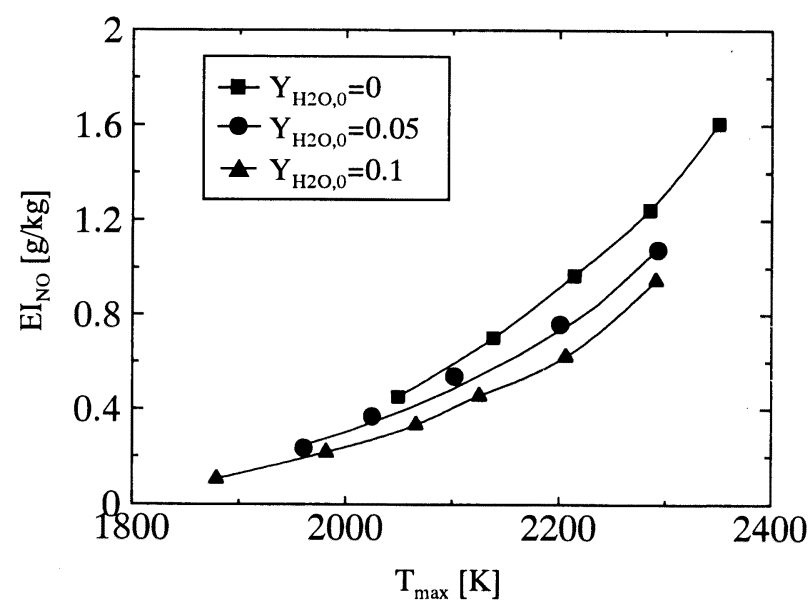

Fig. 4 Relation between $E I_{\text {No }}$ and maximum flame temperature

さらに, $\mathrm{NO}_{\mathrm{x}}$ の生成に与える反応動力学的効果を検討するため に, $i$ 番目の素反応のみによる化学種 $k$ の生成量で定義された Emission Index $E I_{\mathrm{k}, \mathrm{l}}$ を用いた。

\section{2. 計算結果と検討}

\section{$2.1 M_{\mathrm{k}}$ および $\boldsymbol{E} I_{\mathrm{No}}$ と最高火炎温度 $T_{\max }$ の関係}

水蒸気を添加あるいは添加しない場合について, 初期温度 $T_{0}$ の増加に伴う最高火炎温度 $T_{\max }$ と NOの Emission Index $E I_{\mathrm{No}}$ の変化を Fig. 2 と Fig. 3 に示す. 水蒸気の添加の有無にかかわら

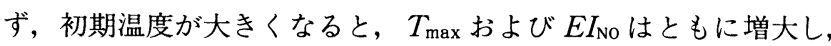
特に, $E I_{\mathrm{N} O}$ はその増加割合が大きくなる，また，水蒸気を添加し た場合には，火炎温度は大きく低下し，EI No は著しく減少する. 一例として, 初期温度 $T_{0}=600 \mathrm{~K}$ の条件で質量分率 0.05 の水蒸 気を添加する場合, 火炎の最高温度は約 $200 \mathrm{~K}$ 低下し, $E I_{\mathrm{No}}$ は水 蒸気を添加しない場合の約 $40 \%$ まで低減される.

火炎温度低下という水蒸気添加の物理的な影響を除いて, 化学 反応論的効果のみを考察するために, これらの結果から求めた $E I_{\text {No }}$ と最高火炎温度の関係を Fig. 4 に示す.この四から明らかな ように，最高火炎温度が同一となる条件で比較した場合でも，水 蒸気の添加量が多い場合ほど $E I_{\mathrm{No}}$ が減少し, $\mathrm{NO}_{\mathrm{x}}$ の生成量にか なり相違が見られる.したがって, 水蒸気添加による $\mathrm{NO}_{\mathrm{x}}$ の低減 


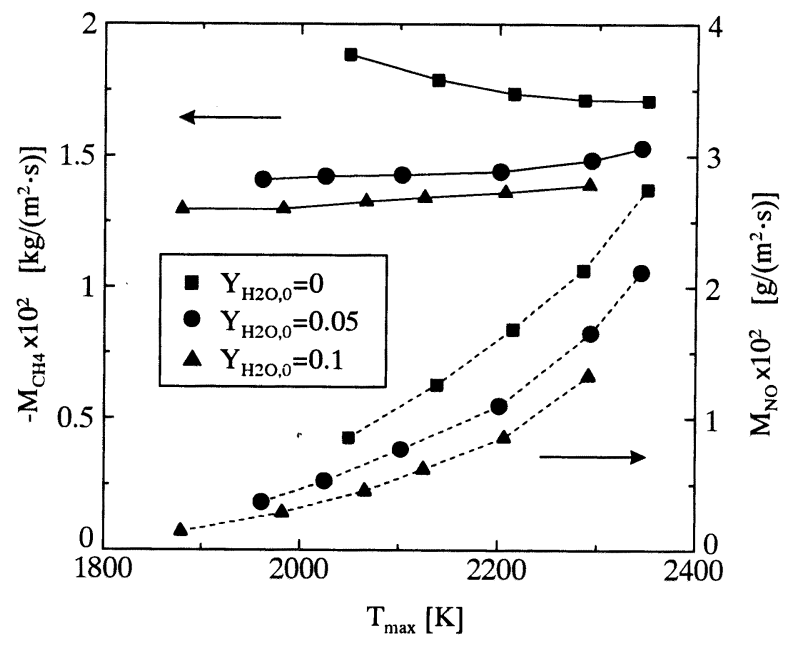

Fig. 5 Relations between $-M_{\mathrm{CH}_{4}}$ and $M_{\mathrm{No}}$ and maximum flame temperature

に対して化学反応論的な効果があるものと考えられる.

さらに, 燃料メタンの消費速度一 $M_{\mathrm{CH}_{4}}$ および $\mathrm{NO}$ の生成速度 $M_{\mathrm{No}}$ と最高火炎温度 $T_{\max }$ の関係を Fig. 5 に示す. 同じ $T_{\max }$ にお いて水蒸気の添加量が多い場合ほど, $M_{\mathrm{No}}$ と- $M_{\mathrm{CH}_{4}}$ はともに小さ くなるが, 一 $M_{\mathrm{CH}_{4}}$ に比較して $M_{\mathrm{No}}$ の減少割合がより大きく, この ことが $E I_{\text {No }}$ の低減の原因である.また, 一 $M_{\mathrm{CH}_{4}}$ は火炎最高温度に あまり依存しないが, $M_{\mathrm{No}}$ は $T_{\max }$ が大きくなると急増し, $\mathrm{NO}_{\mathrm{x}}$ 生 成と火炎温度の間の非線形性を示している。

\section{2 水蒸気添加の効果に対する化学反応論的検討}

従来の研究により, Prompt NO 機構の大略は次の通りである ことが知られている (Takeno et al., 1998). まず, 空気中の $\mathrm{N}_{2}$ と炭化水素の分解過程で生じる活性炭化水素 $\left(\mathrm{CH}, \mathrm{CH}_{2}\right.$ など) と の反応により $\mathrm{HCN}$ が生成され, この $\mathrm{HCN}$ から $\mathrm{NCO}, \mathrm{CN}$ ある いは $\mathrm{NH}$ が直接的あるいは間接的に生成され，さらに $\mathrm{N}$ に変換 される.この $\mathrm{N}$ から $\mathrm{NO}$ が生成されるが, 次の素反応の寄与が著 しく大きい.

$$
\mathrm{N}+\mathrm{OH}=\mathrm{NO}+\mathrm{H}
$$

また,このようにして生成されるNOの一部は火炎中で $\mathrm{HCNO}, \mathrm{HNO}, \mathrm{HCN}$ 等に変換される.ここでは, $\mathrm{CH}, \mathrm{HCN}$, $\mathrm{N}$ おび $\mathrm{OH}$ のような中間活性成分が Prompt NOの生成に重 要な役割を担っている.

本研究では, 水蒸気添加が $\mathrm{NO}_{\mathrm{x}}$ 低減に与之る効果を化学反応論 的に検討するために, 最高火炎温度がほぼ一致する $Y_{\mathrm{H}_{2} 0,0}=0$, $T_{0}=600 \mathrm{~K}$ と $Y_{\mathrm{H}_{2} 0,0}=0.05, T_{0}=800 \mathrm{~K}$ の条件について, 水蒸気を 添加あるいは添加しない場合の NO および関連するラジカルの 素反応別の生成特性を調べた.

2.2 .1 NOの生成速度 NOの生成に大きく寄与する素反 応別の生成速度分布を Fig. 6 に示寸. 図からわかるように, Thermal NOの生成に関係する素反応 (R 179) の生成速度は非常に小 さく, NOは主に上記の素反応 (R 180)により生成され, 次の素 反応（R 274）により消滅する. また, NOは素反応 (R 212) によ り燃料側では生成し, 空気側では消滅する。

$$
\begin{aligned}
& \mathrm{N}+\mathrm{O}_{2}=\mathrm{NO}+\mathrm{O} \\
& \mathrm{HCCO}+\mathrm{NO}=\mathrm{HCNO}+\mathrm{CO} \\
& \mathrm{H}+\mathrm{NO}+\mathrm{M}=\mathrm{HNO}+\mathrm{M}
\end{aligned}
$$

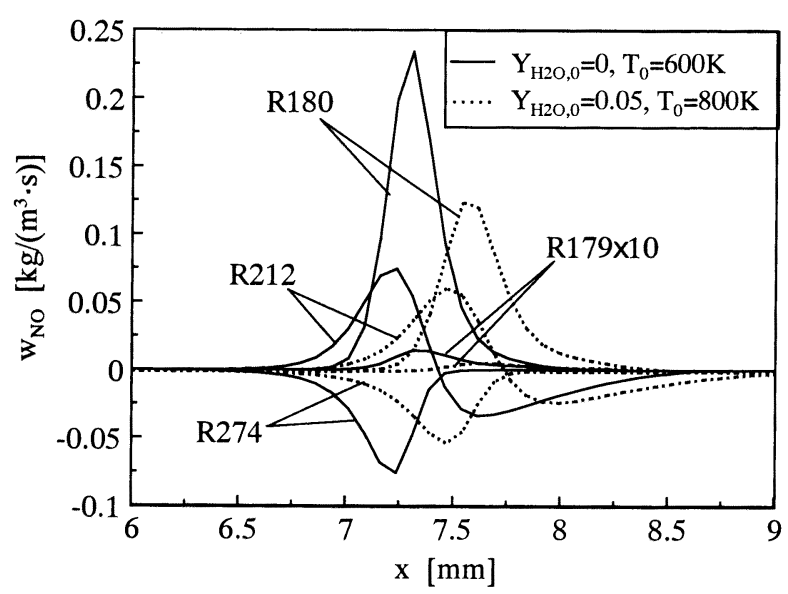

Fig. 6 Profiles of NO mass production rate by various elementary reactions

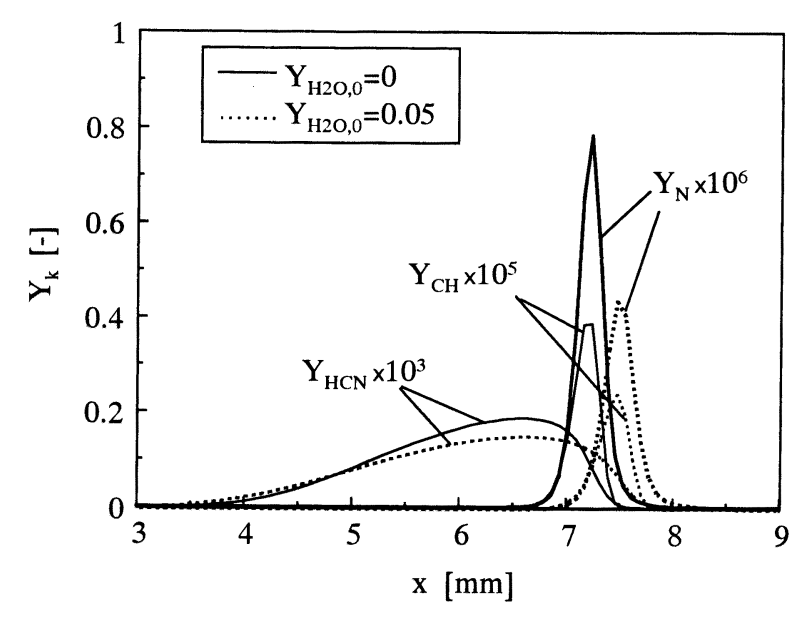

Fig. 7 Profiles of mass fraction of species $\mathrm{HCN}, \mathrm{CH}$ and $\mathrm{N}$

の有無にかかわらず支配的であることがわかる，また，水蒸気を 添加した場合 $\left(Y_{\mathrm{H}_{2} 0,0}=0.05, T_{0}=800 \mathrm{~K}\right)$ には, 関与する素反応 別の生成速度は, 減少割合は異なるが, いずれも小さくなる。こ れは, 添加される水蒸気は本来燃焼反応の最終的な生成物である ため, ルシャトリエの原理により燃焼反応の進行が抑制されるこ とによると考之られる.なお, 水蒸気を添加した場合には, 添加 しない場合に比べて対向流全体の運動量勾配が小さく, 空気側の 運動量の割合が小さいために, 生成速度分布のピークの幅が広が $\eta$, 位置が空気側にややずれる。

2.2 .2 中間の活性化学種の濃度分布 水蒸気を添加しない 場合および添加した場合について, 化学種 $\mathrm{CH}, \mathrm{HCN}$ およひ $\mathrm{N}$ の 濃度分布を Fig. 7 に示寸. 最高火炎温度が同一となる条件におい て, 水蒸気を添加した場合, $\mathrm{CH}, \mathrm{HCN}$ および $\mathrm{N}$ の濃度はともに 小さくなることがわかる.

さらに, 水蒸気の熱分解に関係する化学種 $\mathrm{H}, \mathrm{O}$ および $\mathrm{OH} の$ 濃度分布を Fig. 8 に示す. 最高火炎温度が同一となる条件におい て, 水蒸気を添加した場合, $\mathrm{H}$ と $\mathrm{O}$ の濃度がやや減少し, $\mathrm{OH}$ 濃 度は増加することがわかる. $\mathrm{OH}$ ラジカルの濃度が増えると, 素反 応 (R 180)による NO の生成反応が促進されるため, $\mathrm{NO}_{\mathrm{x}}$ の抑制 にマイナスの効果となる. しかし， $\mathrm{CH}$ ラジカルの濃度が減少し， $\mathrm{CH}$ に起因する $\mathrm{HCN}$ と N ラジカル濃度が減少するため, $\mathrm{NO}_{\mathrm{x}}$ の 生成が全体としては抑制されるものと考えられる。

2.2.3 $\mathrm{HCN}$ の生成速度および $E I_{\mathrm{HCN}, 1}$ 水蒸気を添加ある

第 25 巻 第 6 号 (1999) 


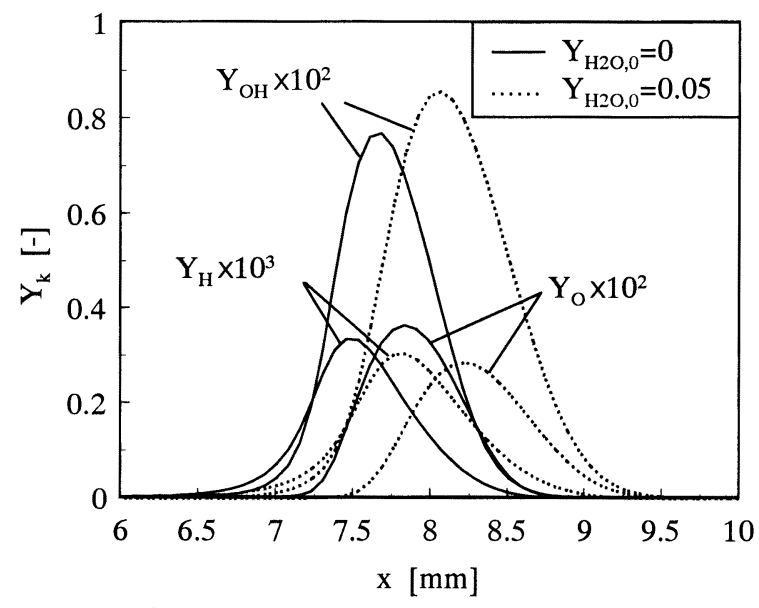

Fig. 8 Profiles of mass fraction of species $\mathrm{OH}, \mathrm{O}$ and $\mathrm{H}$

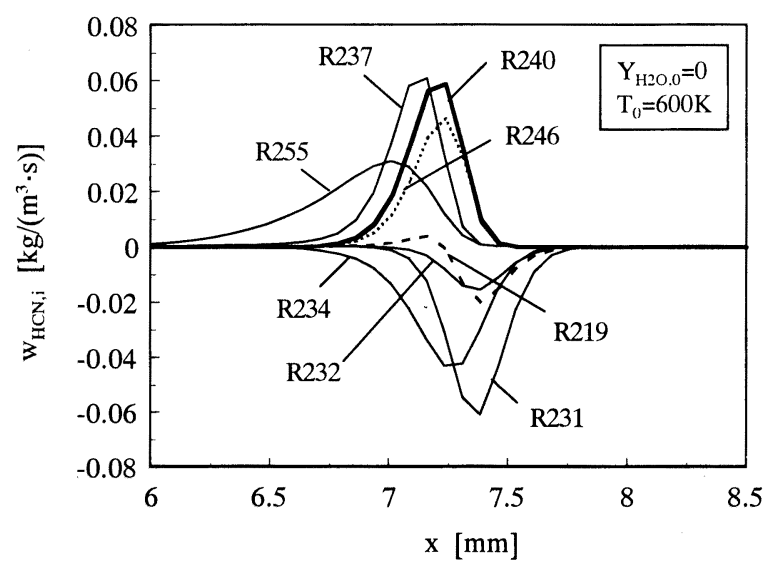

Fig. 9(a) Profiles of HCN mass production rate by various elementary reactions without steam addition $\left(T_{0}=600 \mathrm{~K}, Y_{\mathrm{H}_{2} 0,0}=0\right)$

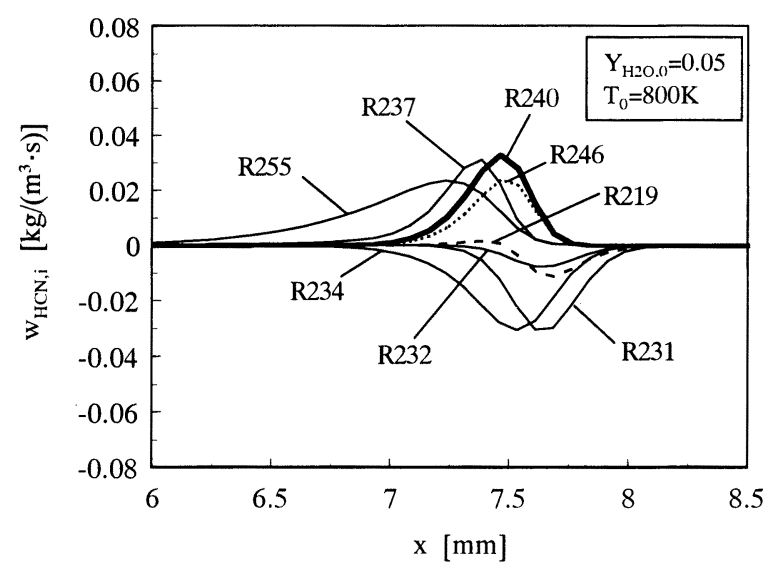

Fig. 9(b) Profiles of HCN mass production rate by various elementary reactions with steam addition $\left(T_{0}=800 \mathrm{~K}, Y_{\mathrm{H}_{2} 0,0}=0.05\right)$

いは添加しない場合について，HCN ラジカルの生成に大きく寄 与する素反応を取り上げ，素反応別の生成速度分布を Fig. 9(a) および Fig. 9(b)に示す. HCN ラジカルの生成には次の 4 個の素 反応の寄与が大きく，水蒸気を添加した場合にはいずれの生成速 度分布のピークとも低下することがわかる.

$$
\begin{array}{lr}
\mathrm{CH}_{3}+\mathrm{NO}=\mathrm{HCN}+\mathrm{H}_{2} \mathrm{O} & (\mathrm{R} 255) \\
\mathrm{H}_{2} \mathrm{CN}+\mathrm{M}=\mathrm{HCN}+\mathrm{H}+\mathrm{M} & (-\mathrm{R} 237) \\
\mathrm{CH}+\mathrm{N}_{2}=\mathrm{HCN}+\mathrm{N} & (\mathrm{R} 240)
\end{array}
$$

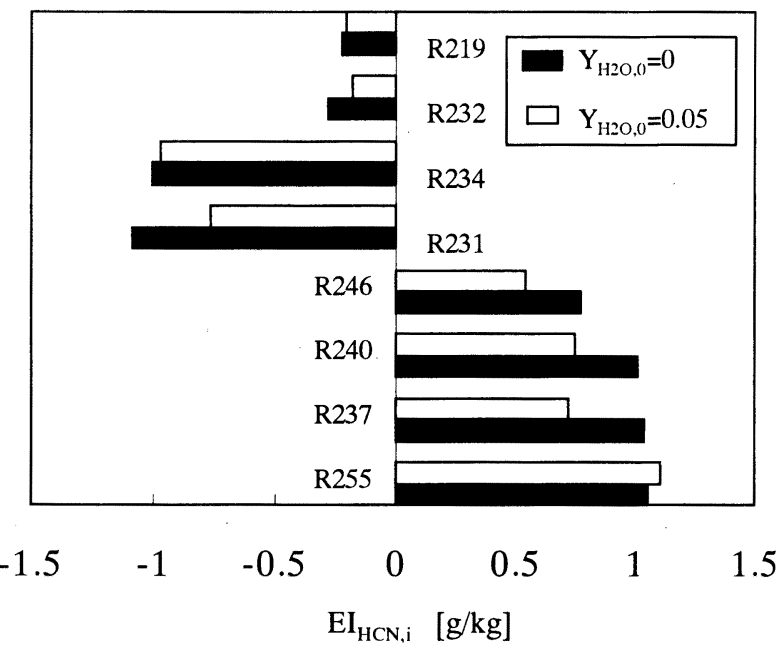

Fig. 10 Contributions to $\mathrm{HCN}$ emission index from various elementary reactions

$\mathrm{CH}+\mathrm{NO}=\mathrm{HCN}+\mathrm{O}$

これらの素反応の中で，素反応（R 255）と（R 246）は NO を 消費しており，正味の $\mathrm{NO}$ 生成には寄与しない。 また，素反応($\mathrm{R} 237$ ）は反応物質の $\mathrm{H}_{2} \mathrm{CN}$ が主に素反応 $\mathbf{C H}_{3}+\mathbf{N}=\mathbf{H}_{2} \mathbf{C N}+\mathbf{H}$ （R275）により， $\mathrm{N}$ を消費して生成されており，やはり正味の NO 生成にはあまり寄与しない。したがって, 素反応 (R 240) が NO 生成に寄与する $\mathrm{HCN}$ の最も重要な生成素反応である.

一方, $\mathrm{HCN}$ の消滅には次の 4 個の素反応の寄与が大きく, 水蒸 気を添加した場合にはやはりいずれも HCN の消滅速度が低下す る.

$$
\begin{aligned}
& \mathrm{HCN}+\mathrm{O}=\mathrm{NCO}+\mathrm{H} \\
& \mathrm{HCN}+\mathrm{OH}=\mathrm{HOCN}+\mathrm{H} \\
& \mathrm{HCN}+\mathrm{O}=\mathrm{NH}+\mathrm{CO} \\
& \mathrm{HCN}+\mathrm{OH}=\mathrm{CN}+\mathrm{H}_{2} \mathrm{O}
\end{aligned}
$$

これらの素反応により, Prompt NO 機構の反応経路が形成さ れ, $\mathrm{HCN}$ からさらに $\mathrm{NCO}, \mathrm{CN}$ あるいは $\mathrm{NH}$ が直接的あるいは 間接的に生成されることになる。

Fig.10 は以上の $\mathrm{HCN}$ に関係する素反応の $E I_{\mathrm{HCN}, 1}$ をまとめた ものである. 図からわかるように, 水蒸気を添加した場合, HCN ラジカルの生成および消滅の素反応はともに抑制されるが, HCN の消滅に寄与する素反応の $E I_{\mathrm{HCN}, \mathrm{I}}$ の減少に比べて, $\mathrm{HCN}$ の生成 に寄与する素反応の $E I_{\mathrm{HCN}, \mathrm{i}}$ の減少の割合が明らかに大きい.

\subsection{4. $\mathrm{CH}$ の生成速度拉よび $E I_{\mathrm{CH}, \mathrm{I}} \quad \mathrm{HCN}$ の生成における} 最も重要な素反応 (R 240) が水蒸気添加により抑制される機構を 解明するためには，メタンの分解生成物である $\mathrm{CH}$ ラジカルの生 成特性を考察することが重要となる.

解析結果によると, $\mathrm{CH}$ ラジカルの生成・消滅には以下の 3 個 の素反応の寄与が大きい。これらの素反応別の生成速度分布およ び $E I_{\mathrm{CH}, 1}$ を Fig. 11 および Fig. 12 に示す.

$$
\begin{array}{lr}
\mathrm{H}+\mathrm{CH}_{2}=\mathrm{CH}+\mathrm{H}_{2} & \text { (-R 126) } \\
\mathrm{OH}+\mathrm{CH}_{2}=\mathrm{CH}+\mathrm{H}_{2} \mathrm{O} & \text { (R 93) } \\
\mathrm{CH}+\mathrm{H}_{2} \mathrm{O}=\mathrm{H}+\mathrm{CH}_{2} \mathrm{O} & \text { (R 127) }
\end{array}
$$

水蒸気を添加した場合には素反応別の生成速度がやはりいずれ も小さくなるが, $\mathrm{CH}$ の生成反応 $(-\mathrm{R} 126)$ の $E I_{\mathrm{CH}, 1}$ は小さくなる のに対して, $\mathrm{CH}$ の消滅反応 (R 127) の $E I_{\mathrm{CH}, 1}$ はほとんど変化し ない. したがって, $\mathrm{CH}$ ラジカルは, 水蒸気の添加により, 生成量 が減少する上に, 消費量は変化しないことになり, その結果, $\mathrm{CH}$ 


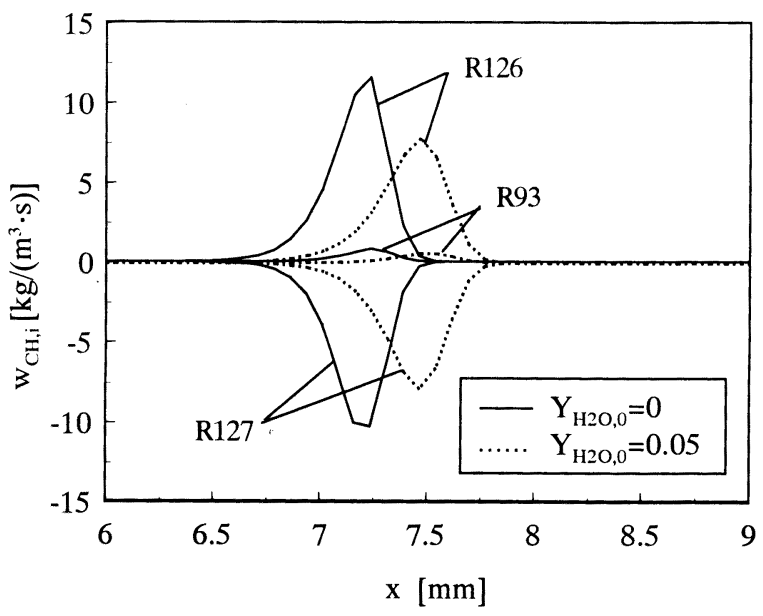

Fig. 11 Profiles of $\mathrm{CH}$ mass production rate by various elementary reactions

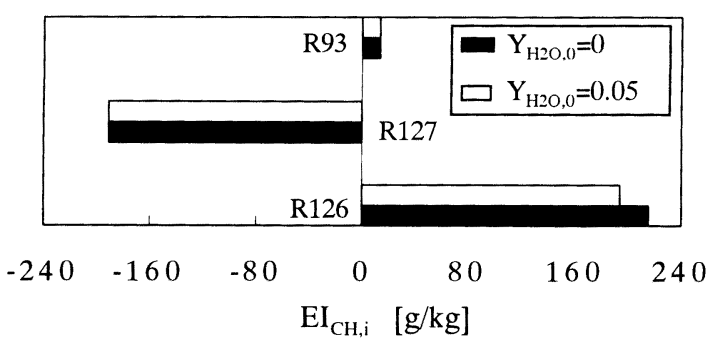

Fig. 12 Contributions to $\mathrm{CH}$ emission index from various elementary reactions

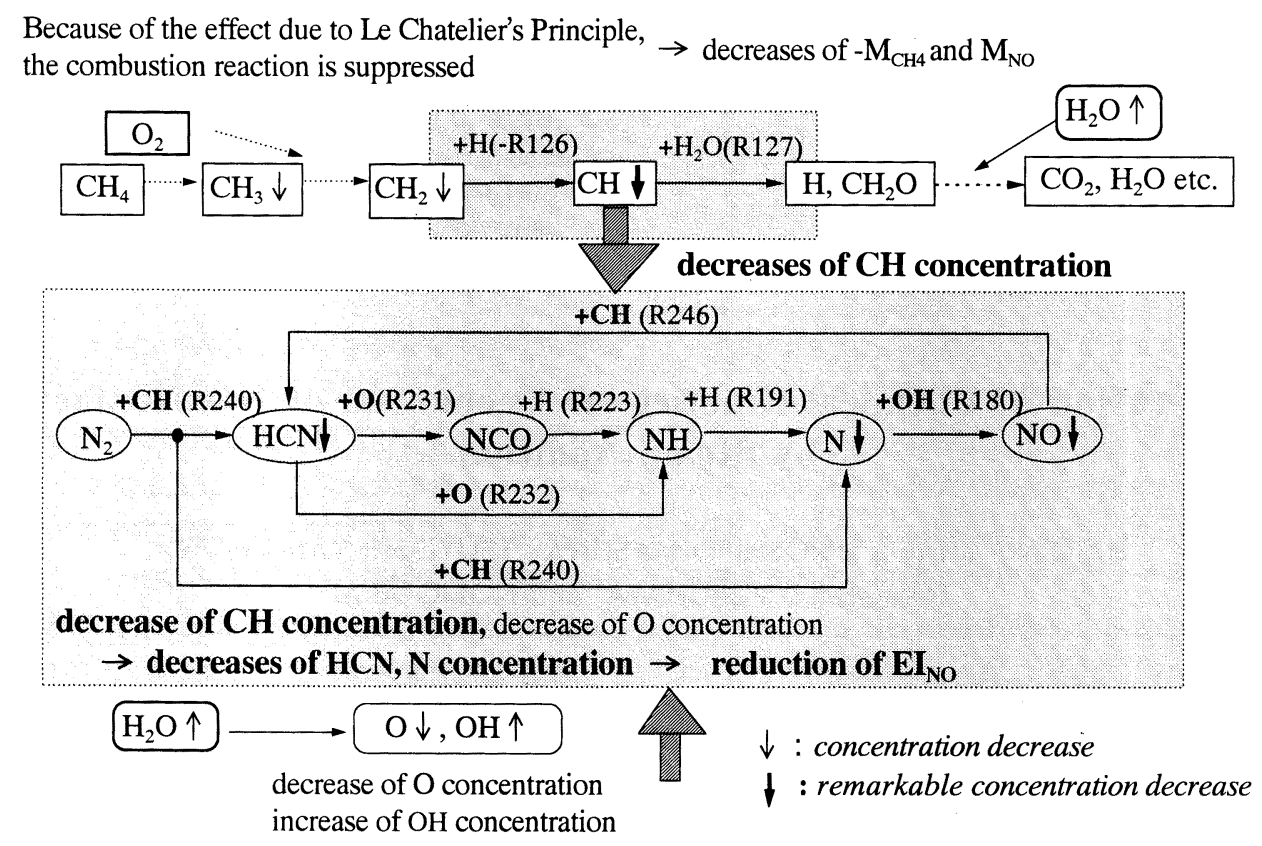

Fig. 13 Mechanisms of NO reduction by steam addition

濃度が大きく減少することになる．

\section{$2.3 \mathrm{NO}_{\mathrm{x}}$ 低滅機構の検討}

以上の検討に基づいて, 水蒸気添加が燃焼反応に及ぼす影響, および $\mathrm{NO}_{\mathrm{x}}$ 生成の抑制に与える効果をまとめて Fig. 13 に示し， NOの低減機構について考察する.

まず，水蒸気を添加した場合には，ルシャトリエの原理により 燃焼反応の進行が抑制されるため, 添加しない場合に比べて，メ タン $\mathrm{CH}_{4}$ の消費速度が小さくなり, $\mathrm{NO}$ 生成に関連する重要な $\mathrm{CH}, \mathrm{HCN}, \mathrm{N}$ などのラジカルに関与する各素反応における生成 消滅速度も低下寸る，次に，水蒸気を添加した場合，水蒸気とメ タンの分解生成物との反応が促進されるため, $\mathrm{CH}$ 濃度が一層減 少する。これによって，Nラジカルまでの一連の反応はともに抑 制され， $\mathrm{HCN} ， \mathrm{NCO}, \mathrm{N}$ などの濃度がすべて減少する。さらに, 水蒸気添加による $\mathrm{O}$ 濃度の減少も $\mathrm{HCN}, \mathrm{NCO}$ などの抑制に有効 である. その結果, NO 濃度の減少だけではなく, $M_{\mathrm{No}}$ の減少割合 がー $M_{\mathrm{CH}_{4}}$ より大きくなり，NOの Emission Index は低減される ことになる.
水蒸気を添加した場合, $\mathrm{OH}$ の濃度が増加し, $\mathrm{NOx}$ の抑制には マイナスの効果となるが, 上述の $\mathrm{CH}$ 濃度の減少の効果の方が大 きく, Nラジカルの発生がすでに効果的に抑制されるため, $\mathrm{NO}_{\mathrm{x}}$ の生成が全体として抑制されるものと考えられる.

\section{結言}

水蒸気添加による $\mathrm{NO}_{\mathrm{x}}$ 低減には, 火炎温度の低下という物理的 な効果の他に, 化学反応論的な効果もあることを詳細素反応機構 を用いた数值解析により確かめた。特に, 対向流拡散火炎におけ る $\mathrm{NO}_{\mathrm{x}}$ の生成量について, 最高火炎温度が同一となる条件で比較 することにより, 化学反応論的効果のみを抽出して検討を行い, 以下のような結果を得た。

（1）水蒸気を添加した場合，ルシャトリエの原理により燃焼 反応の進行が抑制されるため, ほとんどの素反応の反応速 度が低下し，NOの生成量も抑制される。

（2）各素反応における反応速度の低下割合は異なり，特に， $\mathrm{CH}$ の消滅速度の低下割合が小さいことにより, $\mathrm{CH}$ 濃度 
の減少が顕著になる。このことは NO 生成の抑制に大きく 寄与する。

（3）水蒸気添加による $\mathrm{OH}$ 濃度の増加は $\mathrm{NO}_{\mathrm{x}}$ 生成の抑制に マイナスの効果となるが, $\mathrm{CH}$ 濃度の減少より, $\mathrm{HCN}$ と $\mathrm{N}$ の濃度が減少し, $\mathrm{NO}_{\mathrm{x}}$ の生成が全体としては抑制されるこ とになる。

（4）水蒸気の添加量が多いほど，メタン消費量の減少割合に 比べて, $\mathrm{NO}$ 生成量の減少割合が大きいために，EI $E I_{\mathrm{No}}$ は低 減する。

[謝 辞] 本研究は新エネルギー・産業技術総合開発機構 (NEDO) 新 規産業創造型提案公募事業 (プロジェクト ID No. 97 省 E 02-002)の一環と して行われた. 付して謝意を表する.また, 本研究の一部は（財）鉄鋼業環 境保全技術開発基金の第 18 回環境研究助成によって行われた.ここに謝意 を表す。

\section{Literature cited}

Arai, N., N. Kobayashi, K. Nakano and A. Matsunami ; "Proposal of Chemical Gas Turbine and Characteristics of Pressurized LowNOx Combustion," Pacific RIM Int. Conf. on Environmental Control Combustion Processes, Paper 6 A, p. 1-10, Hawaii, USA (1994)

Arai, N. and N. Kobayashi ; "Challenges for Development of Highly Efficient Gas Turbine System: The Chemical Gas Turbine System," Proc. of the ASME Int. Joint Power Generation Conf., 1, p. 423-430, Denver, USA (1997)
GRI ; http://www.me.berkeley.edu/gri_mech/, 1995

Kee, R. J., F. M. Rupley and J. A. Miller ; CHEMKIN-II : A Fortran Chemical Kinetics Package for the Analysis of Gas-Phase Chemical Kinetics., SAND 89-8009 (1989)

Li, S. C., N. Llincic and F. A. Williams ; "Reduction of NOx Formation by Water Sprays in Strained Two-Stage Flames," ASME J. Eng. for Gas Turbines and Power, 119, 836-843 (1997)

Miyauchi, T. and Y. Mori ; "Effect of Steam Addition on NO Formation,” Nensho Kenkyu, 55, 11-24 (1980)

Smooke, M. D. ; Reduced Kinetic Mechanisms and Asymptotic Approximations for Methane-Air Flames, Springer-Verlag, Bellin, Germany (1991)

Takeno, T. and M. Nishioka ; "NO Formation Mechanisms of Methane Air Flames," Nensho Kenkyu, 111, 3-15 (1998)

Takeno, T. and M. Nishioka; "Species Conservation and Emission Indices for Flames Described by Similarity Solutions," Combustion and Flame, 92, 465-468 (1993)

Watanabe, H. ; “Cogeneration," Journal of Japan Energy Academy, 7, 713-723 (1997)

Yamashita, H., D. Zhao, T. Furuhata and N. Arai ; "Numerical Analysis of $\mathrm{NO}_{\mathrm{x}}$ Reduction by Steam Injection Using Detailed Chemical Kinetics," Proceedings of the Second Trabzon International Energy and Environment Symposium, p. 241-245, Trabzon, Turkey (1998)

Yamashita, H. ; "Numerical Study on $\mathrm{NO}_{x}$ Production of Transitional Fuel Jet Diffusion Flame," Nihon Kikaigakukai Ronbunshu (B), 65 -630, 783-789 (1999)

\title{
Consideration of Chemical Kinetics on Mechanism of NOx Reduction by Steam Addition
}

\section{DAIQING ZHAO ${ }^{1}$, HIROSHI YAMASHITA ${ }^{2}$, TSUYOSHI YAMAMOTO ${ }^{3}$, TOMOHIKO FURUHATA ${ }^{4}$ and NORIO ARAI ${ }^{4}$}

\author{
${ }^{1}$ New Energy and Industrial Technology Development Organization, Tokyo 170-6028 \\ ${ }^{2}$ Department of Mechanical Engineering, Nagoya University, Nagoya 464-8603 \\ ${ }^{3}$ Department of Chemical Engineering, Nagoya University, Nagoya 464-8603 \\ ${ }^{4}$ Research Center for Advanced Energy Conversion, Nagoya University, Nagoya 464-8603
}

\begin{abstract}
Key words: $\mathrm{NO}_{\mathrm{x}}$ reduction, steam addition, counterflow diffusion flame, detailed chemical kinetics.

In the steam-injected combustion field where the Prompt mechanism controls $\mathrm{NO}_{\mathrm{x}}$ formation, a decrease in flame temperature physically affects the $\mathrm{NO}_{\mathbf{x}}$ reduction. In addition, it is anticipated that the changes of concentrations of active radicals $(\mathrm{CH}, \mathrm{OH}, \mathrm{H}$, etc.) due to steam addition bring about a chemical kinetic effect on the $\mathrm{NO}_{\mathrm{x}}$ reduction.

In order to investigate the chemical reaction effect of steam addition on $\mathrm{NO}_{\mathrm{x}}$ reduction, we carried out numerical calculations of counterflow diffusion flame using detailed chemical kinetics, where the maximum flame temperature were adjusted to the same value by varying the initial temperatures. Under the same maximum flame temperature, the NO emission index decreases with increasing amount of steam addition, and the concentration and mass production rate of $\mathrm{CH}, \mathrm{HCN}$ and $\mathrm{N}$, etc., related to $\mathrm{NO}_{\mathrm{x}}$ formation also decrease when steam is added. Consequently, we clarify chemical kinetic effect of steam addition on NOx reduction.
\end{abstract}

